\title{
Fate of radiocesium in freshwater aquatic plants and algae in the vicinity of the Fukushima Daiichi nuclear power plant
}

\author{
Yoshito Sasaki $^{1} \cdot$ Hironori Funaki $^{1} \cdot$ Syatei Iri $^{1} \cdot$ Terumi Dohi $^{1} \cdot$ Hiroki Hagiwara $^{1}$
}

Received: 20 October 2015/ Accepted: 1 December 2015/Published online: 20 January 2016

(C) The Author(s) 2016. This article is published with open access at Springerlink.com

\begin{abstract}
The behavior of radiocesium $\left({ }^{137} \mathrm{Cs}\right)$ in aquatic plants (five species) and algae (three genera) grown in either a river (one sampling point) or pond (four sampling points) in the vicinity of the Fukushima Daiichi nuclear power plant was investigated. The ${ }^{137} \mathrm{Cs}$ concentration of $<0.45-\mu \mathrm{m}$ fractions of water taken from the river and ponds was between $5.01 \times 10^{-1}$ and $2.98 \mathrm{~Bq} / \mathrm{L}$, while that of sediment was between $4.85 \times 10^{3}$ and $5.72 \times 10^{4} \mathrm{~Bq} / \mathrm{kg}$ dry weight. The ratio of ${ }^{137} \mathrm{Cs}$ concentration of sediment/ water in ponds was $\sim 10^{4}$. The sediment-to-plant transfer factor (TF) $\left[\left({ }^{137} \mathrm{Cs}\right.\right.$ concentration $\mathrm{Bq} / \mathrm{kg}$ dry weight $\left.{ }_{\text {plant }}\right) \times$ $\left({ }^{137} \mathrm{Cs}\right.$ concentration $\mathrm{Bq} / \mathrm{kg}$ dry weight sediment $^{-1}$ ] was also measured. For aquatic plants, the highest value was 5.55 for Potamogeton crispus from the river, while the lowest was $3.34 \times 10^{-2}$ for $P$. distinctus from a pond. There were significant differences in values between aquatic plants belonging to the same genus. The water-to-plant TF $\left[{ }^{137} \mathrm{Cs}\right.$ concentration $\mathrm{Bq} / \mathrm{kg}$ dry weight $\left.{ }_{\text {plant }}\right) \times\left({ }^{137} \mathrm{Cs}\right.$ concentration $\left.\mathrm{Bq} / \mathrm{L}_{\text {water }}\right)^{-1}$ ] of filamentous algae (Spirogyra sp.) and cyanobacteria (coexisting Anabaena sp. and Microcystis sp.) were $2.39 \times 10^{3}$ and $1.26 \times 10^{3}$, respectively. The ${ }^{137} \mathrm{Cs}$ concentration of cyanobacteria in pond water was $4.87 \times 10^{-1} \mathrm{~Bq} / \mathrm{L}$, which was the same order of magnitude as the ${ }^{137} \mathrm{Cs}$ concentration of pond water. Enrichment of ${ }^{137} \mathrm{Cs}$ in cyanobacteria was not observed.
\end{abstract}

Handling Editor: Yoshiki Sohrin.

Yoshito Sasaki

sasaki.yoshito@jaea.go.jp

1 Fukushima Environmental Safety Center, Japan Atomic

Energy Agency, Sahei 8F, 1-29, Okitama-cho,

Fukushima-shi, Fukushima 960-8034, Japan
Keywords Radiocesium - Fukushima Daiichi nuclear power plant $\cdot$ Aquatic plants $\cdot$ Algae

\section{Introduction}

As a result of the accident at Fukushima Daiichi nuclear power plant (FDNPP) caused by the Great East Japan earthquake on 11 March 2011, a large amount of radionuclides-such as cesium $\left({ }^{134} \mathrm{Cs}\right.$, 2.06-year half-life; ${ }^{137} \mathrm{Cs}$, 30.2-year half-life) and iodine ( ${ }^{131} \mathrm{I}, 8.04$-day half-life)were released into the environment (Chino et al. 2011). Of major concern is the presence of radiocesium $\left({ }^{137} \mathrm{Cs}\right)$, which has a long half-life and thus has a continuing presence in the environment. However, the long-term nuclide migration of ${ }^{137} \mathrm{Cs}$ in the environment is not well understood.

Radiocesium has been detected in fish inhabiting rivers in the Fukushima Prefecture (Ministry of the Environment 2013, 2014), which becomes incorporated in their bodies because of biological and physical cycles (Avery 1996) involving aquatic plants and algae in freshwater. Polar and Bayülgen (1991) reported that aquatic plants concentrate ${ }^{137} \mathrm{Cs}$ more than terrestrial plants. Fukuda et al. (2014) reported that several species of aquatic plants and algae had high radionuclide recovery efficiency under culture conditions in the absence of potassium but in the presence of ${ }^{137} \mathrm{Cs}$.

There have been many studies regarding ${ }^{137} \mathrm{Cs}$ transfer in terrestrial plants but few reports on aquatic plants (Avery 1996). Although one report exists regarding the transfer of ${ }^{137} \mathrm{Cs}$ released from the FDNPP to algae in seawater (Kawai et al. 2014), thus far there have been no studies regarding this transfer in freshwater. In this study, ${ }^{137} \mathrm{Cs}$ concentrations of water, sediment, aquatic plants, and algae in a river and artificial agriculture ponds within $\sim 7 \mathrm{~km}$ of the FDNPP were examined. As well, transfer factors (TFs) - 
representing the ratio of incorporation of radionuclides from sediment and water into plants-were compared.

\section{Materials and methods}

\section{Sampling}

We investigated the transfer of ${ }^{137} \mathrm{Cs}$ to aquatic plants and algae in ponds and a river in the region contaminated with radionuclides released by the accident at the FDNPP. Locations of the river (one point: KUMR2) and ponds (four points: OKUMA24, OKUMA70, FUTABA55, and FUTABA48) from which samples were obtained are shown in Fig. 1. Samples were collected from July to September 2013 using a 225- $\mathrm{cm}^{2}$ Ekman-Birge bottom sampler (RIGO, Tokyo, Japan) at the midpoint of the pond, and with a plastic ladle (4 L; shaft length, $120 \mathrm{~cm}$ ) (SANKA, Nigata, Japan) for the river. Collected sediment samples were dried to a constant weight at $105{ }^{\circ} \mathrm{C}$. After being mixed to ensure consistency, sediment samples were placed in 80-ml polystyrene containers (V7 containers) for measurement of ${ }^{137} \mathrm{Cs}$ concentration. Water depth measurements were obtained from the center of the ponds and at the aquatic plant collection points of the river. Measurements of $\mathrm{pH}$ in the ponds were obtained using a multiparameter waterquality-meter multimonitoring system (W-23XD, HORIBA, Ltd., Kyoto, Japan). In the river, a $\mathrm{pH}$ meter (B-712, HORIBA, Ltd.) was used after water sampling.

After their fresh weight was measured, collected aquatic plants and algae were dried to a constant weight at $90{ }^{\circ} \mathrm{C}$ in a forced convection constant temperature oven (DMK300, Yamato Scientific Co., Ltd., Tokyo, Japan). Cyanobacteria were collected in the vicinity of the pond intake, which is where they were concentrated. Surface water containing cyanobacteria that was sampled using a ladle was passed through a sieve (mesh size, $250 \mu \mathrm{m}$ ) to remove debris. Once the surface water was centrifuged (6654 g, $5 \mathrm{~min}, 3-$ 16 L, Sigma Laborzentrifugen $\mathrm{GmbH}$, Osterode am Harz, Germany), the algal precipitate was collected. After their fresh weight was measured, collected algal fractions were placed on a Durapore ${ }^{\circledR}$ polyvinylidene fluoride membrane filter (pore size, $0.45 \mu \mathrm{m}$; diameter, $47 \mathrm{~mm}$; HVLP4700, Merck Millipore, MA, USA) and dried to a constant weight at $90{ }^{\circ} \mathrm{C}$ in the forced-convection constant-temperature oven (DMK300) before measuring ${ }^{137} \mathrm{Cs}$ concentration. The percent moisture content of aquatic plants and algae was determined using the following equation:

Percent moisture content $=($ Fresh weight - Dry weight $) /$

Fresh weight
Fig. 1 Sampling points and Fukushima Daiichi Nuclear Power Plant (FDNPP). Squatic plants and algae obtained from the river and ponds around the FDNPP: a Potamogeton crispus L., b Trapa bispinosa Roxb. var. japonica Nakai, c Nymphaea tetragona Georgi, d Potamogeton distinctus A. Benn. e Spirogyra sp., f coexisting Anabaena sp. and Microcystis sp.

\section{Identification of aquatic plants and algae}

Aquatic plants were identified based on their morphology, with reference to Kadono (1994). Algae were also identified based on their morphology, which was observed using a microscope (VHX-2000, Keyence Corporation, Osaka, Japan), with reference to Hirose and Yamagishi (1977).

\section{Measurement of ${ }^{137} \mathrm{Cs}$ concentration}

Radiocesium concentrations of water $(<0.45-\mu \mathrm{m}$ fractions in 500-ml plastic containers), dried sediment [in 80-ml plastic (V7) containers], dried aquatic plants (in 100-ml containers), and cyanobacteria (on 47-mm-diameter membrane filters) were measured using an n-type, high-purity Ge-detector (GMX40P4-76 germanium detector, Seiko EG\&G ORTEC, Tokyo, Japan) with $40 \%$ relative efficiency. Gamma-ray emission at $604 \mathrm{keV}\left({ }^{134} \mathrm{Cs}\right)$ and $661 \mathrm{keV}\left({ }^{137} \mathrm{Cs}\right)$ was also measured. For the pulse-height analysis, a multichannel analyzer (MCA7600, Seiko EG\&G ORTEC) was used in line with spectrum analysis software (Gamma Studio, Seiko EG\&G ORTEC). Efficiency calibration was carried out with a multiple gammaray-emitting standard source (including ten nuclides) packed in the same type of vessel (Eckert and Ziegler Isotope Products, CA, USA) or in a plastic disc with the same active area $(\varphi 42 \mathrm{~mm})$ as the membrane filter (Eckert and Ziegler Nuclitec GmbH, Braunschweing, Germany). Radiocesium decay was corrected on the sampling dates. The ${ }^{137} \mathrm{Cs}$ concentration measurements showed a $1 \sigma$ counting error.

\section{Calculation of TF}

Sediment-to-plant and water-to-plant TFs were determined using Eqs. (2) and (3), where $C^{p}$ is the plant ${ }^{137} \mathrm{Cs}$ concentration $\left(\mathrm{Bq} / \mathrm{kg}\right.$ dry weight), $C^{w}$ is the water ${ }^{137} \mathrm{Cs}$ concentration $(\mathrm{Bq} / \mathrm{L})$, and $C^{s}$ is the sediment ${ }^{137} \mathrm{Cs}$ concentration $(\mathrm{Bq} / \mathrm{kg})$.

$\mathrm{C}^{\mathrm{p}}=$ Water-to-plant $\mathrm{TF} \times \mathrm{C}^{\mathrm{w}}$

$\mathrm{C}^{\mathrm{p}}=$ Sediment-to-plant $\mathrm{TF} \times \mathrm{C}^{\mathrm{s}}$ 

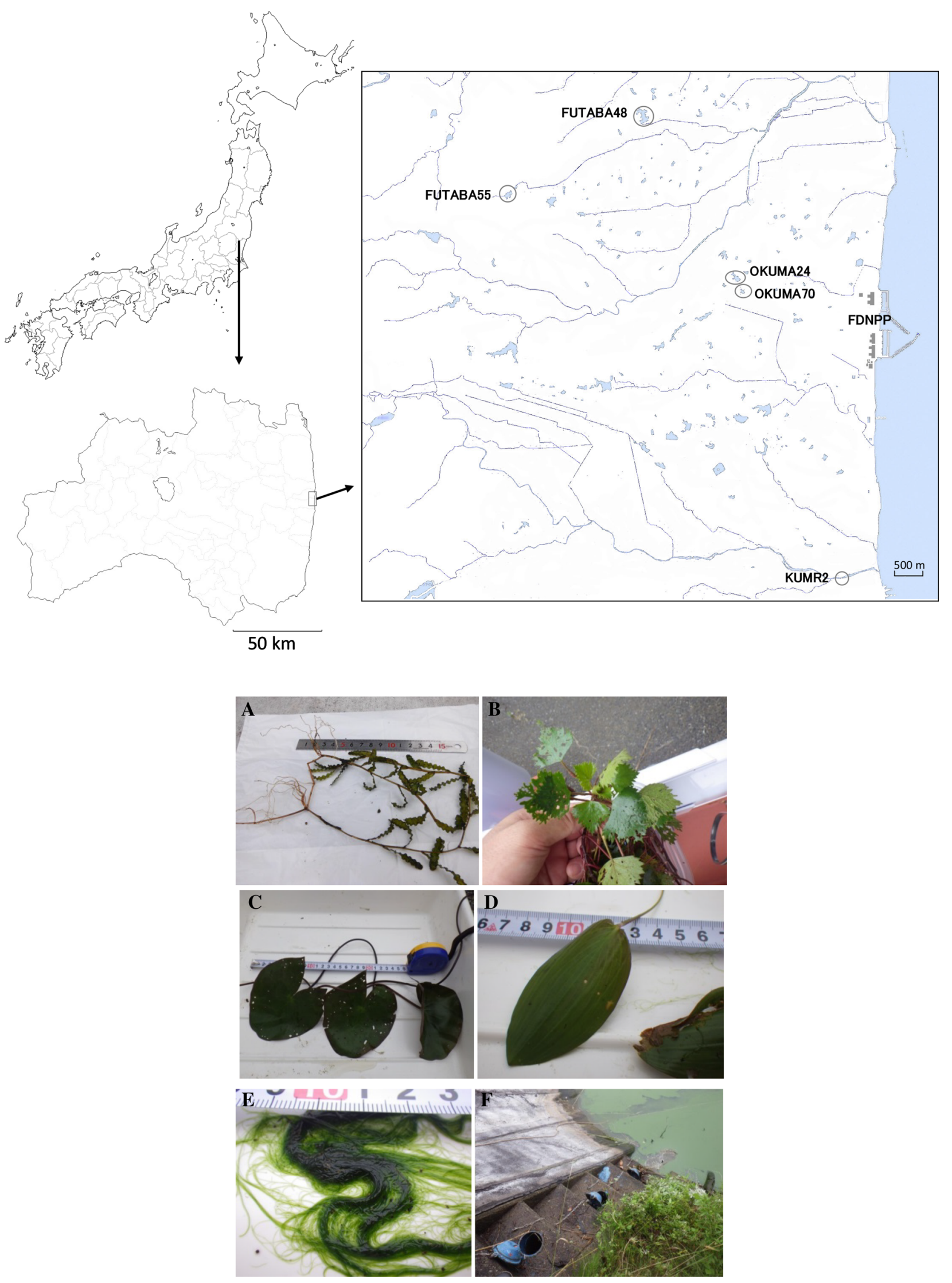


\section{Results and discussion}

Pond FUTABA48, in which blue-green algae (cyanobacteria) was found, was 240-cm deep, which was deeper than ponds containing aquatic plants rooted to the bottom (depth, 120-170 cm). The $\mathrm{pH}$ of pond water increases due to consumption of carbon dioxide through photosynthesis associated with the blooming of cyanobacteria (Paerl and Ustach 1982); therefore, the $\mathrm{pH}$ of pond FUTABA48 was higher; and that of water near the intake, where the cyanobacteria were concentrated, was 9.1 and was even higher in the center of the pond. The metabolism of cyanobacteria is influenced by changes in $\mathrm{pH}$ (Coleman and Colman 1981, Wang et al. 2011), whereas the effect of $\mathrm{pH}$ changes on ${ }^{137} \mathrm{Cs}$ concentration in cyanobacteria is unknown. With the exception of pond FUTABA48, the $\mathrm{pH}$ of surface water in the ponds and river was $\sim 7$ (Table 1).

The ${ }^{137} \mathrm{Cs}$ concentration in surface water and sediment is listed in Table 1 . The highest concentration of ${ }^{137} \mathrm{Cs}$ in surface water was $2.98 \mathrm{~Bq} / \mathrm{L}$ in FUTABA55, while the lowest was $5.01 \times 10^{-1} \mathrm{~Bq} / \mathrm{L}$ in KUMR2. The highest concentration in sediment was $5.72 \times 10^{4} \mathrm{~Bq} / \mathrm{kg}$ in FUTABA55, while the lowest was $4.85 \times 10^{3} \mathrm{~Bq} / \mathrm{kg}$ in KUMR2. After the Chernobyl nuclear power plant accident, concentration of ${ }^{137} \mathrm{Cs}$ in river water was estimated by catchment inventory of ${ }^{137}$ Cs (Santschi et al. 1990, Smith et al. 2004, 2005). The same behavior of ${ }^{137} \mathrm{Cs}$ was observed in the Fukushima River after the FDNPP accident (Yoshimura et al. 2015). The ratio of ${ }^{137} \mathrm{Cs}$ concentration of sediment/water in the ponds was $\sim 10^{4}$ (Table 1), suggesting that ${ }^{137} \mathrm{Cs}$ concentration in water and sediment is in equilibrium.

Sakaguchi et al. (2015) reported that ${ }^{137} \mathrm{Cs}$ in the river water $(<0.45 \mu \mathrm{m}$ fraction) was present exclusively as the dissolved species rather than being adsorbed on suspended solids or complexed with organic materials. Dissolved ${ }^{137} \mathrm{Cs}$ species in the water are easily incorporated into plants. However, further investigation of the relationship between plant growth and dissolved ${ }^{137} \mathrm{Cs}$ concentration is required. Photographs of aquatic plants and algae from the river and ponds in the vicinity of the FDNPP are shown in Fig. 1. The moisture content and ${ }^{137} \mathrm{Cs}$ concentration of aquatic plants and algae are shown in Table 1 . The water content of aquatic plants was $\sim 90 \%$, with that of algae being higher. The ${ }^{137} \mathrm{Cs}$ concentrations of aquatic plants and algae were between $10^{3}$ and $10^{4} \mathrm{~Bq} / \mathrm{kg}$. The ${ }^{137} \mathrm{Cs}$ concentration of Potamogeton crispus was $2.69 \times 10^{4} \mathrm{~Bq} /$ $\mathrm{kg}$, which was the highest value for the collected aquatic plants. The ${ }^{137} \mathrm{Cs}$ concentration of Trapa bispinosa obtained from an adjacent pond, with similar water depth and $\mathrm{pH}$, was similar, as the ${ }^{137} \mathrm{Cs}$ concentrations in the sediment and water of the pond were nearly identical. $T$. bispinosa seeds contain starch and are edible; however, seeds were not collected as this study was performed prior to fruiting. The ${ }^{137} \mathrm{Cs}$ concentrations of Nymphaea tetragona and $P$. distinctus were $10^{3} \mathrm{~Bq} / \mathrm{kg}$, which was lower than the values for other aquatic plants. The cyanobacteria consisted of coexisting Anabaena sp. and Microcystis sp. The ${ }^{137} \mathrm{Cs}$ concentrations of filamentous algae and cyanobacteria were $10^{3} \mathrm{~Bq} / \mathrm{kg}$. Adsorbed ${ }^{137} \mathrm{Cs}$ on suspended solids of the clay and silt fraction is the main contributor to the transport of ${ }^{137} \mathrm{Cs}$ in water (Matsunaga et al. 2015). Cesium incorporated into clay minerals will not readily enter subsequent biological cycles as it is strongly adsorbed (Cremers et al. 1988; Valcke and Cremers 1994). In addition to the contribution from suspended solids, the movement of ${ }^{137} \mathrm{Cs}$-contaminated microalgae with water flow leads to the potential spread of contamination. The ${ }^{137} \mathrm{Cs}$ concentration of the cyanobacterial fraction was $4.87 \times 10^{-1} \pm 1.74 \times 10^{-2} \mathrm{~Bq} / \mathrm{L}$, which was the same order of magnitude as the ${ }^{137} \mathrm{Cs}$ concentration in the water. In this case, ${ }^{137} \mathrm{Cs}$ migration associated with the movement of cyanobacteria is limited as the ${ }^{137} \mathrm{Cs}$ concentration of cyanobacteria was low. As there is no data regarding changes in cell number and/or species of cyanobacteria, further investigation is required.

Calculated TF values are given in Table 1 . The highest sediment-to-plant TF in aquatic plants was 5.55 for $P$. crispus, while that of T. bispinosa was between $4.46 \times 10^{-1}$ and 1.10 . Although $P$. crispus and $P$. distinctus belong to the same genus, there was a difference of two orders of magnitude in their sediment-to-plant TF values. There is also a difference in the growth form of these two species, with $P$. crispus having submerged leaves and $P$. distinctus having floating leaves. The sediment-to-plant TF values of $N$. tetragona and $P$. distinctus were $8.30 \times 10^{-2}$ and $3.34 \times 10^{-2}$, respectively, which were lower than those of T. bispinosa, though all three species have floating leaves. However, each aquatic plant grew under different conditions in the river and ponds, and the impacts of these differences in growth form and growing conditions on sediment-to-plant TF are unknown. As an example of the impact of these differences, TFs of a cultivated cabbage were $2.1 \times 10^{-3}$ and $3.3 \times 10^{-1}$, differing by two orders of magnitude as a result of different cultivation conditions (Tsukada and Hasegawa 2002). To clarify these effects, further investigation is required.

Soil-to-plant TF values $\left[\left({ }^{137} \mathrm{Cs}\right.\right.$ concentration $\mathrm{Bq} / \mathrm{kg}$ dry weight $\left._{\text {plant }}\right) \times\left({ }^{137} \mathrm{Cs}_{\text {concentration } \mathrm{Bq} / \mathrm{kg} \text { dry weight }} \text { soil }\right)^{-1}$ ] of wild terrestrial plants grown in arable land contaminated by the FDNPP accident were between $6 \times 10^{-3}$ and $7 \times 10^{-1}$ (Yamashita et al. 2014), which were lower than the sediment-to-water TF values of $P$. crispus and $T$. bispinosa. This is potentially due to the fact that the aquatic plants were grown in conditions that allowed for easy incorporation of dissolved ${ }^{137} \mathrm{Cs}$, compared with the terrestrial plants. 
Table 1 Investigation site and date, $\mathrm{pH}$ of water, radiocesium $\left({ }^{137} \mathrm{Cs}\right)$ concentrations in water, sediment, aquatic plants and algae, and transfer factors (TF)

\begin{tabular}{|c|c|c|c|c|c|c|c|c|c|c|c|}
\hline $\begin{array}{l}\text { Investigation } \\
\text { site }\end{array}$ & $\begin{array}{l}\text { Sampling } \\
\text { date }\end{array}$ & \multicolumn{2}{|c|}{$\begin{array}{l}\text { Distance from } \\
\text { FDNPP }(\mathrm{km})\end{array}$} & \multicolumn{2}{|c|}{$\begin{array}{l}\text { Depth of } \mathrm{pH} \\
\text { water }(\mathrm{cm})\end{array}$} & \multicolumn{2}{|c|}{$\begin{array}{l}{ }^{137} \mathrm{Cs} \text { concentration of } \\
\text { surface water }(\mathrm{Bq} / \mathrm{L})\end{array}$} & \multicolumn{2}{|c|}{$\begin{array}{l}{ }^{137} \mathrm{Cs} \text { concentration of } \\
\text { sediment }(\mathrm{Bq} / \mathrm{kg})\end{array}$} & \multicolumn{2}{|c|}{$\begin{array}{l}\text { Ratio of }{ }^{137} \mathrm{Cs} \\
\text { concentration of } \\
\text { sediment/water }\end{array}$} \\
\hline KUMR2 & $\begin{array}{l}2013 \\
\text { Aug. } 28\end{array}$ & 4.5 & & 80 & 7.3 & \multicolumn{2}{|l|}{$\begin{array}{l}5.01 \times 10^{-1} \\
\pm 1.27 \times 10^{-1}\end{array}$} & \multicolumn{2}{|c|}{$\begin{array}{l}4.85 \times 10^{3} \\
\pm 6.51 \times 10^{2}\end{array}$} & \multicolumn{2}{|c|}{$\begin{array}{l}9.7 \times 10^{3} \\
\pm 2.8 \times 10^{3}\end{array}$} \\
\hline OKUMA24 & $\begin{array}{l}2013 \mathrm{Jul} \\
17\end{array}$ & 2.5 & & 140 & 6.7 & \multicolumn{2}{|l|}{$\begin{array}{l}1.05 \\
\pm 1.98 \times 10^{-1}\end{array}$} & \multicolumn{2}{|c|}{$\begin{array}{l}3.32 \times 10^{4} \\
\pm 2.15 \times 10^{2}\end{array}$} & \multicolumn{2}{|c|}{$\begin{array}{l}3.2 \times 10^{4} \\
\pm 6.0 \times 10^{3}\end{array}$} \\
\hline OKUMA70 & $\begin{array}{l}2013 \mathrm{Jul} \\
18\end{array}$ & 2.5 & & 120 & 6.8 & \multicolumn{2}{|l|}{$\begin{array}{l}9.60 \times 10^{-1} \\
\pm 1.99 \times 10^{-1}\end{array}$} & \multicolumn{2}{|c|}{$\begin{array}{l}1.78 \times 10^{4} \\
\pm 1.41 \times 10^{2}\end{array}$} & \multicolumn{2}{|c|}{$\begin{array}{l}1.9 \times 10^{4} \\
\pm 3.8 \times 10^{3}\end{array}$} \\
\hline FUTABA55 & $\begin{array}{l}2013 \mathrm{Jul} \\
25\end{array}$ & 7 & & 170 & 7.1 & \multicolumn{2}{|l|}{$\begin{array}{l}2.98 \\
\pm 7.30 \times 10^{-1}\end{array}$} & \multicolumn{2}{|c|}{$\begin{array}{l}5.72 \times 10^{4} \\
\pm 2.69 \times 10^{2}\end{array}$} & \multicolumn{2}{|c|}{$\begin{array}{l}1.9 \times 10^{4} \\
\pm 4.7 \times 10^{3}\end{array}$} \\
\hline FUTABA48 & $\begin{array}{l}2013 \mathrm{Jul} \\
26\end{array}$ & 5.5 & & 290 & 8.6 & \multicolumn{2}{|l|}{$\begin{array}{l}8.00 \times 10^{-1} \\
\pm 2.03 \times 10^{-1}\end{array}$} & \multicolumn{2}{|c|}{$\begin{array}{l}9.49 \times 10^{3} \\
\pm 1.27 \times 10^{2}\end{array}$} & \multicolumn{2}{|c|}{$\begin{array}{l}1.2 \times 10^{4} \\
\pm 3.0 \times 10^{3}\end{array}$} \\
\hline $\begin{array}{l}\text { Investigation } \\
\text { site }\end{array}$ & \multicolumn{2}{|c|}{$\begin{array}{l}\text { Common name } \\
\text { of the taxon }\end{array}$} & $\begin{array}{l}\text { Sampling } \\
\text { date }\end{array}$ & \multicolumn{2}{|c|}{ Scientific name } & $\begin{array}{l}\% \mathrm{H}_{2} \mathrm{O} \\
\text { dry weight }\end{array}$ & \multicolumn{2}{|c|}{$\begin{array}{l}{ }^{137} \mathrm{Cs} \text { concentration } \\
\text { of plant }(\mathrm{Bq} / \mathrm{kg})\end{array}$} & \multicolumn{2}{|c|}{$\begin{array}{l}\text { Water-to-plant } \\
\text { transfer factor }\end{array}$} & $\begin{array}{l}\text { Sediment-to-plant } \\
\text { transfer factor }\end{array}$ \\
\hline KUMR2 & \multicolumn{2}{|c|}{ Aquatic plant } & $\begin{array}{l}2013 \\
\text { Aug. } 28\end{array}$ & \multicolumn{2}{|c|}{$\begin{array}{l}\text { Potamogeton } \\
\text { crispus }\end{array}$} & 90 & \multicolumn{2}{|c|}{$\begin{array}{l}2.69 \times 10^{4} \\
\pm 3.29 \times 10^{2}\end{array}$} & \multicolumn{2}{|c|}{$\begin{array}{l}5.37 \times 10^{4} \\
\pm 1.36 \times 10^{4}\end{array}$} & $\begin{array}{l}5.55 \\
\pm 1.01 \times 10^{-1}\end{array}$ \\
\hline OKUMA24 & \multicolumn{2}{|c|}{ Aquatic plant } & $\begin{array}{l}2013 \mathrm{Jul} \\
17\end{array}$ & \multicolumn{2}{|c|}{ Trapa bispinosa } & 91 & \multicolumn{2}{|c|}{$\begin{array}{l}1.48 \times 10^{4} \\
\pm 2.52 \times 10^{2}\end{array}$} & \multicolumn{2}{|c|}{$\begin{array}{l}1.41 \times 10^{4} \\
\pm 2.67 \times 10^{3}\end{array}$} & $\begin{array}{l}4.46 \times 10^{-1} \\
\pm 8.12 \times 10^{-3}\end{array}$ \\
\hline \multirow[t]{2}{*}{ OKUMA70 } & \multicolumn{2}{|c|}{ Aquatic plant } & $\begin{array}{l}2013 \mathrm{Jul} \\
18\end{array}$ & \multicolumn{2}{|c|}{ Trapa bispinosa } & 90 & \multicolumn{2}{|c|}{$\begin{array}{l}1.96 \times 10^{4} \\
\pm 2.30 \times 10^{2}\end{array}$} & $\begin{array}{l}2.04 \times 10 \\
\pm 4.24 \times 1\end{array}$ & & $\begin{array}{l}1.1 \\
\pm 1.56 \times 10^{-2}\end{array}$ \\
\hline & Aquatic pl & & $\begin{array}{l}2013 \mathrm{Jul} \\
18\end{array}$ & $\begin{array}{r}\text { Nymphae } \\
\text { tetragor }\end{array}$ & & 89 & $\begin{array}{l}4.75 \times \\
\pm 9.66\end{array}$ & & $\begin{array}{l}1.59 \times 10 \\
\pm 3.92 \times 1\end{array}$ & & $\begin{array}{l}8.30 \times 10^{-2} \\
\pm 1.73 \times 10^{-3}\end{array}$ \\
\hline FUTABA55 & Aquatic $\mathrm{pl}$ & & $\begin{array}{l}2013 \mathrm{Jul} \\
18\end{array}$ & $\begin{array}{r}\text { Potamoge } \\
\text { distinct }\end{array}$ & & 93 & $\begin{array}{l}1.91 \times \\
\pm 5.27\end{array}$ & & $\begin{array}{l}6.41 \times 10 \\
\pm 1.58 \times 1\end{array}$ & & $\begin{array}{l}3.34 \times 10^{-2} \\
\pm 9.35 \times 10^{-4}\end{array}$ \\
\hline & $\begin{array}{l}\text { Alga } \\
\text { (Filamen } \\
\text { Alga) }\end{array}$ & & $\begin{array}{l}2013 \mathrm{Jul} \\
25\end{array}$ & Spirogyro & & 97 & $\begin{array}{l}7.11 \times \\
\pm 1.94\end{array}$ & $\begin{array}{l}0^{3} \\
10^{2}\end{array}$ & $\begin{array}{l}2.39 \times 10 \\
\pm 5.88 \times 1\end{array}$ & & $\begin{array}{l}1.24 \times 10^{-1} \\
\pm 3.44 \times 10^{-3}\end{array}$ \\
\hline FUTABA48 & $\begin{array}{l}\text { Alga } \\
\text { (Cyanob }\end{array}$ & teria) & $\begin{array}{l}2013 \text { Sep } \\
2\end{array}$ & $\begin{array}{r}\text { *Anabaer } \\
\text { Microc } \mathrm{J}\end{array}$ & $\begin{array}{l}\text { sp., } \\
\text { tis sp. }\end{array}$ & 99 & $\begin{array}{l}1.01 \times \\
\pm 3.61\end{array}$ & & $\begin{array}{l}1.26 \times 10 \\
\pm 3.24 \times 1\end{array}$ & & $\begin{array}{l}1.06 \times 10^{-1} \\
\pm 1.47 \times 10^{-2}\end{array}$ \\
\hline
\end{tabular}

* Coexisting

The highest value of water-to-plant TF was $5.37 \times 10^{4}$ $(P$. crispus $)$ and the lowest $6.41 \times 10^{2}(P$. distinctus $)$. The water-to-plant $\mathrm{TF}$ of duckweed (a species of Lemnaceae) under cultured test conditions was between $2.3 \times 10^{3}$ and $3.9 \times 10^{3}$ (Polar and Bayülgen 1991). The water-to-plant $\mathrm{TF}$ of ${ }^{137} \mathrm{Cs}$ in aquatic plants and algae was between $6.41 \times 10^{2}$ and $5.37 \times 10^{4}$, which was close to the value reported by Polar and Bayülgen (1991). As filamentous algae and cyanobacteria do not have roots, they obtain the nutrients necessary for growth directly from the water and through vertical movement with gas vesicles, such as $A n$ abaena and Microcystis, respectively (Ganf and Oliver, 1982). The water-to-plant and sediment-to-plant TF values of filamentous algae and cyanobacteria were on the same order. The soil-to-plant TF values $\left[\left({ }^{137} \mathrm{Cs}\right.\right.$ concentration
$\mathrm{Bq} / \mathrm{kg}$ dry weight $\left.{ }_{\text {plant }}\right) \times\left({ }^{137} \mathrm{Cs}\right.$ concentration $\mathrm{Bq} / \mathrm{kg}$ dry weight $\left._{\text {soil }}\right)^{-1}$ ] of terrestrial cyanobacteria Nostoc commune contaminated by the FDNPP accident were between $9.8 \times 10^{-1}$ and $9.59 \times 10$ (Sasaki et al. 2013). The waterto-plant TF values of marine macroalgae (seaweed) contaminated by the accident were between $\sim 8 \times 10$ and $5 \times 10^{2}$ (Kawai et al. 2014). Through screening for useful tools with the potential to decontaminate ${ }^{137} \mathrm{Cs}$, Fukuda et al. (2014) found that algae (a species of Eustigmatophyceae) and duckweed (Lemno aoukikusa) had high ${ }^{137} \mathrm{Cs}$ removal capacities, as determined by culture tests using non-potassium-containing and ${ }^{137} \mathrm{Cs}$-containing media. Potassium and cesium are congeners, i.e., cesium displays similar behavior to that of potassium. Thus, these species of alga and duckweed have the potential to be useful tools 
for decontamination. Through this study, we elucidated the behavior of ${ }^{137} \mathrm{Cs}$ in aquatic plants and algae in freshwater environments near the FDNPP.

Acknowledgments We express our sincere thanks to the anonymous reviewers who gave valuable comments. We also thank the members of the Sector of Fukushima Research and Development, Fukushima Environmental Safety Center, JAEA, and we thank Dr. H. Sato (associate professor of Okayama University) for his advice. Moreover, we are grateful to Satoshi Maeda and Tsutomu Okazaki (Sasakino Analytical laboratory, Fukushima Radiation Measurement Group) for their technical help in measurement of ${ }^{137} \mathrm{Cs}$ concentration.

Open Access This article is distributed under the terms of the Creative Commons Attribution 4.0 International License (http://crea tivecommons.org/licenses/by/4.0/), which permits unrestricted use, distribution, and reproduction in any medium, provided you give appropriate credit to the original author(s) and the source, provide a link to the Creative Commons license, and indicate if changes were made.

\section{References}

Avery SV (1996) Fate of caesium in the environment: distribution between the abiotic and biotic components of aquatic and terrestrial ecosystems. J Environ Radioact 30:139-171

Chino M, Nakayama H, Nagai H, Terada H, Katata G, Yamazawa H (2011) Preliminary estimation of release amounts of ${ }^{131} \mathrm{I}$ and ${ }^{137} \mathrm{Cs}$ accidentally discharged from the Fukushima Daiichi nuclear power plant into the atmosphere. J Nucl Sci Technol 48:1129-1134

Coleman JR, Colman B (1981) Inorganic carbon accumulation and photosynthesis in a blue-green alga as a function of external $\mathrm{pH}$. Plant Physiol 67:917-921

Cremers A, Elsen A, De Preter P, Maes A (1988) Quantitative analysis of radiocaesium retention in soils. Nature 335:247-249

Fukuda SY, Iwamoto K, Atsumi M, Yokoyama A, Nakayama T, Ishida K, Inouye I, Shiraiwa Y (2014) Global searches for microalgae and aquatic plants that can eliminate radioactive cesium, iodine and strontium from the radio-polluted aquatic environment: a bioremediation strategy. J Plant Res 127:79-89

Ganf GG, Oliver RL (1982) Vertical separation of light and available nutrients as a factor causing replacement of green algae by bluegreen algae in the plankton of a stratified lake. J Ecol 70:829-844

Hirose H, Yamagishi T (eds) (1977) Illustrations of the Japanese fresh-water algae, Uchida Rokakuho Publishing Co., Ltd, Tokyo, Japan (in Japanese)

Kadono Y (1994) Aquatic plants of Japan, Bun-ichi Sogo Shuppan, Co., Ltd, Tokyo, Japan (in Japanese)

Kawai H, Kitamura A, Mimura M, Mimura T, Tahara T, Aida D, Sato K, Sasaki H (2014) Radioactive cesium accumulation in seaweeds by the Fukushima 1 Nuclear Power Plant accidenttwo years' monitoring at Iwaki and its vicinity. J Plant Res $127: 23-42$
Matsunaga T, Nakanishi T, Atarashi-Andoh M, Takeuchi E, Tsuduki K, Nishimura S, Koarashi J, Otosaka S, Sato T, Nagao S (2015) A passive collection system for whole size fractions in river suspended solids. J Radioanal Nucl Chem 303:1291-1295

Ministry of the Environment (2013, 2014) Radioactive material monitoring surveys of the water. Environment, Marine Organisms, http://www.env.go.jp/en/water/rmms/surveys.html

Paerl HW, Ustach JF (1982) Blue-green algal scums: an explanation for their occurrence during freshwater blooms. Limnol Oceanogr 27:212-217

Polar E, Bayülgen N (1991) Differences in the availabilities of cesium-134, 137 and ruthenium-106 from a Chernobyl-contaminated soil to a water plant, Duckweed, and to the terrestrial plants, bean and lettuce. J Environ Radioact 13:251-259

Sakaguchi A, Tanaka K, Iwatani H, Chiga H, Fan Q, Onda Y, Takahashi Y (2015) Size distribution studies of ${ }^{137} \mathrm{Cs}$ in river water in the Abukuma Riverine system following the Fukushima Dai-ichi Nuclear Power Plant accident. J Environ Radioact 139:379-389

Santschi PH, Bollhader S, Zingg S, Luck A, Farbenkothen K (1990) The selfcleaning capacity of surface waters after radioactive fallout. Evidence from European waters after Chernobyl, 1986-1988. Environ Sci Tech 24:519-527

Sasaki H, Shirato S, Tahara T, Sato K, Takenaka H (2013) Accumulation of radioactive cesium released from Fukushima Daiichi Nuclear Power Plant in terrestrial cyanobacteria Nostoc commune. Microbes Environ 28:466-469

Smith JT, Wright SM, Cross MA, Monte L, Kudelsky AV, Saxen R, Vakulovsky SM, Timms DN (2004) Global analysis of the riverine transport of ${ }^{90} \mathrm{Sr}$ and ${ }^{137} \mathrm{Cs}$. Environ Sci Technol $38: 850-857$

Smith JT, Belova NV, Bulgakov AA, Comans RN, Konoplev AV, Kudelsky AV, Madruga MJ, Voitsekhovitch OV, Zibold G (2005) The "AQUASCOPE" simplified model for predicting ${ }^{89,90} \mathrm{Sr},{ }^{131} \mathrm{I}$, and ${ }^{134,137} \mathrm{Cs}$ in surface waters after a large-scale radioactive fallout. Health Phys 89:628-644

Tsukada H, Hasegawa H (2002) Soil-to-plant transfer of ${ }^{137} \mathrm{Cs}$ and other essential and trace elements in cabbage plants. J Radioanal Nucl Chem 252:219-224

Valcke E, Cremers A (1994) Sorption-desorption dynamics of radiocaesium in organic matter soils. Sci Total Environ 157:275-283

Wang X, Hao C, Zhang F, Feng C, Yang Y (2011) Inhibition of the growth of two blue-green algae species (Microsystis aruginosa and Anabaena spiroides) by acidification treatments using carbon dioxide. Bioresour Technol 102:5742-5748

Yamashita J, Enomoto T, Yamada M, Ono T, Hanafusa T, Nagamatsu T, Sonoda S, Yamamoto Y (2014) Estimation of soil-to-plant transfer factors of radiocesium in 99 wild plant species grown in arable lands 1 year after the Fukushima 1 Nuclear Power Plant accident. J Plant Res 127:11-22

Yoshimura K, Onda Y, Sakaguchi Y, Yamamoto M, Matsuura Y (2015) An extensive study of the concentrations of particulate/ dissolved radiocaesium derived from the Fukushima Dai-ichi Nuclear Power Plant accident in various river systems and their relationship with catchment inventory. J Environ Radioact 139:370-378 